\title{
A valproátterápia túlélésre gyakorolt hatása gliomás betegekben
}

\author{
Alternativ terápiás lebetóség a radiokemoterápia \\ evedményességének javitására
}

\author{
Mezei Tamás dr. ${ }^{1,2^{*}}$ - Mészáros Dávid dr. ${ }^{1^{*}}$ - Pollner Péter $\mathrm{dr} .^{3,4}$ \\ Bagó Attila György dr. ${ }^{2}$ - Fedorcsák Imre dr. ${ }^{2}$ \\ Banczerowski Péter dr. ${ }^{1,2}$. Sipos László dr. ${ }^{1,2}$
}

\author{
${ }^{1}$ Semmelweis Egyetem, Általános Orvostudományi Kar, Idegsebészeti Tanszék, Budapest \\ ${ }^{2}$ Országos Mentális, Ideggyógyászati és Idegsebészeti Intézet, Budapest \\ ${ }^{3}$ MTA-ELTE Statisztikus és Biológiai Fizika Kutatócsoport, Budapest \\ ${ }^{4}$ Semmelweis Egyetem, Egészségügyi Menedzserképző Központ, Budapest
}

\begin{abstract}
Bevezetés: A gliomák, ezen belül a glioblastoma kezelése továbbra is megoldatlan onkológiai problémát jelent. A szekunder szimptómás epilepsziabetegség megjelenése pozitív prognosztikai faktornak tekinthető a korai diagnosztizálás és az antiepileptikumok potenciális tumorellenes hatásának köszönhetően. A valproát túlélést hosszabbító hatása már több mint 20 éve az alap- és klinikai kutatások tárgyát képezi. Napjainkban ismert citotoxikus, proapoptotikus, antiangiogenetikus és hiszton-deacetiláz-gátló hatásmechanizmusa.

Célkitüzés: Kutatásunk célja a valproát túlélést hosszabbító hatásának vizsgálata egy hazai gliomás betegcsoportban. Módszer: Egycentrumos, retrospektív klinikai vizsgálatot végeztünk. A vizsgálatba 122 felnőtt beteget vontunk be, akiknél 2000 januárja és 2018 januárja között supratentorialis glioma miatt mútét történt, és rohamtevékenység miatt antiepileptikumot (valproát, levetiracetám, karbamazepin) szedtek. Egyúttal gyógyszert nem szedő kontrollcsoportot is kialakítottunk. A populációt vizsgálati és kontrollcsoportokra osztottuk $28: 52$ arányban. Leíró statisztikai, Kaplan-Meier- és log-rank analízist végeztünk.

Eredmények: A vizsgált szövettani kategóriák túlélési analízise az irodalmi adatokkal megegyező értékeket mutatott. A progressziómentes (PFS: $\mathrm{p}=0,031)$ és a teljes (OS: $\mathrm{p}=0,027)$ túlélés tekintetében is szignifikáns eltérés mutatkozott a különböző antiepileptikumot szedő betegcsoportok között, amely még kifejezettebbé vált a valproátot és az egyéb antiepileptikumot szedő betegek túlélési idejének összehasonlítása során (PFS: $\mathrm{p}=0,006 ; \mathrm{OS}$ : $\mathrm{p}=0,015$ ). Következtetés: Vizsgálatunkban a valproát betegeink PFS- és OS-idejének meghosszabbodását eredményezte. Az irodalmi adatok és kutatásunk alapján megfontolandónak tartjuk a valproát első vonalban történő alkalmazását onkoterápiában részesülő, epilepsziás, agyi gliomás betegekben.

Orv Hetil. 2021; 162(24): 960-967.
\end{abstract}

Kulcsszavak: valproát, epilepszia, glioma, glioblastoma, túlélés

\section{Supplementary valproate therapy for glioma patients}

\section{An alternative opportunity to enhance the efficiency of radio-chemotherapy}

Introduction: Gliomas still prove to be a serious oncological problem. The presence of epilepsy may present a favorable prognosis due to early diagnosis and the potential antitumor effects of antiepileptic drugs. The survival prolongation effect of valproate has been studied for more than 20 years, nowadays its proapoptotic, anti-angiogenetic, cytotoxic and histone deacetylase inhibitory effects are well known.

Objective: Our goal was to investigate the survival-enhancing effects of valproate in a Hungarian patient cohort of primary brain tumors.

Method: A single-center based retrospective clinical trial was designed. In our study, we included 122 patients harboring supratentorial glioma who underwent surgery and experienced seizures between 2000 January and 2018 January. The patients were grouped by the antiepileptic therapies and survival analysis was performed. 
Results: The Kaplan-Meier curves of the histological categories showed the survival values consistent with the data of the literature. The progression-free (PFS: $\mathrm{p}=0.031$ ) and the overall (OS: $\mathrm{p}=0.027)$ survival of the antiepileptic drug categories were significantly different. It was performed by comparing the valproate group and the population formed by the other groups which also showed a significant increase in the survival values (PFS: $\mathrm{p}=0.006 ;$ OS: $\mathrm{p}=0.015)$.

Conclusion: Our results show that valproate increases the PFS and OS period of glioma patients in comparison to other antiepileptic drugs. Our data suggest that the use of valproic acid should be considered as a first-line antiepileptic agent in certain well-selected epileptic patients with glioma as a supplement to the oncotherapy.

Keywords: valproic acid, epilepsy, glioma, glioblastoma, survival

Mezei T, Mészáros D, Pollner P, Bagó AGy, Fedorcsák I, Banczerowski P, Sipos L. [Supplementary valproate therapy for glioma patients. An alternative opportunity to enhance the efficiency of radio-chemotherapy]. Orv Hetil. $2021 ; 162(24): 960-967$.

(Beérkezett: 2020. november 11.; elfogadva: 2020. december 23.)

\begin{abstract}
Rövidítések
5 -AzaC $=5$-azacitidin; AED $=($ antiepileptic drug $)$ antiepileptikus gyógyszer, antiepileptikum; BNO = Betegségek Nemzetközi Osztályozása; $\mathrm{CBZ}=$ karbamazepin; $\mathrm{CI}=$ (confidence interval) konfidenciaintervallum; HDACi = hiszton-deacetilázinhibitor; HGG = (high-grade glioma) nagy gradusú glioma; LEV = levetiracetám; LGG = (low-grade glioma) kis gradusú glioma; MTA-ELTE = Magyar Tudományos AkadémiaEötvös Loránd Tudományegyetem; $\mathrm{n}=$ esetszám; NA = (not available) nem elérhető; non-GB HGG = (non-glioblastoma, high-grade glioma) nem glioblastoma, nagy gradusú glioma (kivéve glioblastoma); OS = (overall survival) teljes túlélés; $\mathrm{PFS}=$ (progression-free survival) progressziómentes túlélés; $\mathrm{PKC}=($ protein kinase $\mathrm{C})$ proteinkináz $\mathrm{C} ; \mathrm{TMZ}=$ temozolomid; VEGF $=$ (vascular endothelial growth factor) éreredetű növekedési faktor
\end{abstract}

A primer központi idegrendszeri tumorok a felnőttkori daganatos megbetegedések $2 \%$-át teszik ki [1], ezen belül a glioblastoma rendelkezik a legmagasabb incidenciaadatokkal (5,26 fó/100 000 fó) [2]. Malignitás esetén az első lépés a maximális, ugyanakkor megfelelő neurológiai funkciót biztosító mútéti eltávolítás, majd radiokemoterápia és adjuváns monokemoterápia. A medián túlélési idő azonban így is alig éri el a 2 évet [3-5].

Irodalmi adatok alapján a gliomában szenvedó betegek 60-75\%-ánál alakul ki másodlagos epilepsziabetegség; ennek valószínúsége az alacsony gradusú, lassan növő, corticalis laesiók esetén a legmagasabb, és az esetek közel egyharmadában a betegség prezentációs tüneteként jelenik meg [6-8]. A roham megjelenése pozitív prognosztikai faktornak tekinthető, a korai diagnózisalkotás és az antiepileptikumok (AED-k) potenciális antitumorhatásának köszönhetően [9-11].

A valproát fokális epilepsziás rosszullétek esetén másodvonalban használandó AED [12], amelynek antitumorhatására a klinikusok lettek figyelmesek. A 2000-es évek elején derült ki, hogy a szer hiszton-deacetiláz-inhibitor (HDACi) [13]; ezenkívül leírtak több szignálutat is, amelyen keresztül antitumorhatását kifejtheti, de az előbbi a legjelentősebb. Hatására hiperacetilált hisztonmolekulák keletkeznek, amelyek epigenetikai úton csökkentik a kromatin fenntartásához nélkülözhetetlen fehérjék expresszióját, fokozzák a 3-as hiszton metiláltságát. Emellett citotoxikus, proapoptotikus, antiangiogenetikus hatású, és képes fokozni egyes kemoterapeutikumok (például 5-AzaC, doxorubicin, ciszplatin, topoizomeráz-II-inhibitorok stb.) hatását $[14,15]$. Felvetették, hogy a HDACi-k a normál testi sejtekre protektív módon hatnak a radioterápia során, így annak effektivitását a mellékhatások mérséklésével emelni képesek [16]. A fenti eredményekre támaszkodva több retrospektív vizsgálat indult a szer klinikai hatásának statisztikai úton történő bizonyítására.

Vizsgálatunk célja volt a valproát élettartamra gyakorolt hatásának vizsgálata egy magyar gliomás betegcsoportban, ezzel új szupportív terápiás lehetőség megismerése.

\section{Módszer}

Retrospektív adatbázist készítettünk az Országos Mentális, Ideggyógyászati és Idegsebészeti Intézet (korábban: Országos Idegsebészeti Tudományos Intézet) beteganyagából. A beválogatás során felnőtt, mútéten átesett, supratentorialis gliomában szenvedő betegeket kerestünk, akik alapbetegségéhez epilepsziás rosszullét is társult, és betegségük fennállása alatt onkoterápiában részesültek. A szúrés során elsődleges szempont volt a valproátkezelés megléte. A vizsgált időintervallum 2000 januárjától 2018 januárjáig terjedt.

A keresés során az Intézet Hospitaly ${ }^{\circledR}$ programját használtuk. Az 1. táblázat mutatja, mely BNO-kódok segítségével szúkítettük keresésünket. Az elsődleges szürés után 622 beteget gyújtöttünk ki a fent említett kategóriáknak megfelelóen, miszerint supratentorialis, nagyagylebenyt érintő daganatuk volt, illetve ehhez epilepsziás rosszullét is társult. A következő lépésben kiszúr- 
1. táblázat |A BNO-kódok szerint listázott betegek esetszámai

\begin{tabular}{lccc}
\hline BNO-kód & G4010 (n) & G4020 (n) & G4090 (n) \\
\hline C7110 & 76 & 34 & 50 \\
C7120 & 101 & 52 & 54 \\
C7130 & 21 & 4 & 18 \\
C7140 & 8 & 0 & 2 \\
C7180 & 0 & 12 & 26 \\
C7190 & 3 & 18 & 31 \\
C7290 & 0 & 2 & 1 \\
D4300 & 21 & 49 & 39 \\
\hline
\end{tabular}

BNO = Betegségek Nemzetközi Osztályozása

tük adatbázisunkból a metasztatikus eseteket, és csak a primer központi idegrendszeri gliomában szenvedő betegeket vizsgáltuk, azok részletes szövettani besorolásától függetlenül. Ezt követően kiválogattuk a fenti periódusban valproátkezelésben részesült eseteket. Ennek megfelelően a fó betegcsoportunk 31 pácienst tartalmazott (kis gradusú [LGG-] és nagy gradusú gliomás [HGG-] eseteket egyaránt). Az összehasonlíthatóságért hasonló esetszámú és szövettan szerinti eloszlású kontrollcsoportokat hoztunk létre levetiracetám (LEV)-, kar- bamazepin (CBZ)-terápiában részesülő betegekből, illetve antiepileptikus kezelésben nem részesülő (Kontroll) betegekből.

Adatbázisunk ekkor 122 beteg adatait tartalmazta (valproát - 31 fo', LEV - 30 fo", CBZ - 31 f”, „Kontroll”, gyógyszert nem szedő betegek - 30 fö). Minden betegról további információt gyújtöttünk, a pre-, intra-, posztoperatív időszakra vonatkozóan (a beteg életkora, neme, anamnesztikus adatai, fó prezentációs tünete, egyéb neurológiai góctünete[i], epilepsziabetegségének típusa, az alkalmazott gyógyszeres kezelés típusa, annak napi mennyisége, a tumor lokalizációja, az operációk időpontja, a tumor pontos szövettani típusa, a kórházi tartózkodás ideje, a mútétet követő onkoterápia alakulása, az esetleges reoperációk ideje és száma, az első műtét utáni radiológiai és/vagy klinikai progresszió kialakulásának időpontja, a posztoperatív állapot alakulása, a halál időpontja).

A túlélési adatok tovább szúkítették az esetszámot, aminek oka, hogy külföldi betegek is szerepeltek a populációban, illetve az esetek egy részében a páciensek nem Magyarországon folytatták az onkológiai kezelést, vagy jelentési hiba folytán nem kerültek rögzítésre a Nemzeti Rákregiszter adatbázisában. 80 páciens adataival dolgoztunk a statisztikai kiértékelés során. Az egyes jellemzók eloszlását a 2. táblázatban részletesen közöljük.

2. táblázat | Populációnk demográfiai és leíró statisztikai adatai

\begin{tabular}{|c|c|c|c|}
\hline & $\begin{array}{l}\text { Glioblastoma }(\mathrm{GB}) \\
(\mathrm{n}=36)\end{array}$ & $\begin{array}{l}\text { Nem glioblastoma, } \\
\text { nagy gradusú glioma } \\
(\text { non-GB HGG) }(\mathrm{n}=24)\end{array}$ & $\begin{array}{l}\text { Kis gradusú glioma } \\
(\mathrm{LGG})(\mathrm{n}=20)\end{array}$ \\
\hline Átlagéletkor a diagnóziskor (év) & 61 év (35-74 év) & 44 év (35-74 év) & 43 év (24-72 év) \\
\hline $\operatorname{Nem}(\%)$ & $\begin{array}{l}\text { Férfi: } 58 \%(\mathrm{n}=21) \\
\text { Nó: } 42 \%(\mathrm{n}=14)\end{array}$ & $\begin{array}{l}\text { Férfi: } 58 \%(\mathrm{n}=14) \\
\text { Nő: } 42 \%(\mathrm{n}=10)\end{array}$ & $\begin{array}{l}\text { Férfi: } 40 \%(n=8) \\
\text { Nő: } 60 \%(n=12)\end{array}$ \\
\hline Tumorprogresszió (\%) & $77,8 \%(\mathrm{n}=28)$ & $54,2 \%(\mathrm{n}=13)$ & $65 \%(n=13)$ \\
\hline Radiokemoterápia TMZ-vel (\%) & $72 \%(\mathrm{n}=26)$ & $50 \%(\mathrm{n}=12)$ & $25 \%(\mathrm{n}=5)$ \\
\hline $\begin{array}{l}\text { Epilepszia mint első, betegség } \\
\text { prezentáló tünet }(\%)\end{array}$ & $31 \%(\mathrm{n}=11)$ & $38 \%(\mathrm{n}=9)$ & $80 \%(\mathrm{n}=16)$ \\
\hline $\begin{array}{l}\text { Egyéb gyakori jelentkező tünetek } \\
(\%)\end{array}$ & $\begin{array}{l}\text { Aphasia: } 27,8 \%(n=10) \\
\text { Végtaggyengeség: } 16,7 \%(n=6)\end{array}$ & Végtaggyengeség: $17 \%(\mathrm{n}=4)$ & $\begin{array}{l}\text { Végtaggyengeség: } 10 \%(\mathrm{n}=2) \\
\text { Aphasia: } 5 \%(\mathrm{n}=1)\end{array}$ \\
\hline Szövettani diagnózis (\%) & GB: $100 \%$ & $\begin{array}{l}\text { Astrocytoma: } 58 \%(\mathrm{n}=14) \\
\text { Oligodendroglioma: } 42 \% \\
(\mathrm{n}=10)\end{array}$ & $\begin{array}{l}\text { Astrocytoma: } 15 \%(\mathrm{n}=3) \\
\text { Oligodendroglioma: } 60 \%(\mathrm{n}=12) \\
\text { Egyéb kis gradusú glioma: } 25 \%(\mathrm{n}=5)\end{array}$ \\
\hline Szedett antiepileptikum (\%) & $\begin{array}{l}\text { VPA: } 25 \%(n=9) \\
\text { CBZ: } 25 \%(n=9) \\
\text { LEV: } 25 \%(n=9) \\
\text { no AED: } 25 \%(n=9)\end{array}$ & $\begin{array}{l}\text { VPA: } 37,5 \%(\mathrm{n}=9) \\
\text { CBZ: } 16,7 \%(\mathrm{n}=4) \\
\text { LEV: } 33,3 \%(\mathrm{n}=8) \\
\text { no AED: } 12,5 \%(\mathrm{n}=3)\end{array}$ & $\begin{array}{l}\text { VPA: } 50 \%(\mathrm{n}=10) \\
\text { CBZ: } 20 \%(\mathrm{n}=4) \\
\text { LEV: } 30 \%(\mathrm{n}=6) \\
\text { no AED: } 0 \%(\mathrm{n}=0)\end{array}$ \\
\hline Átlagos napi dózis & $\begin{array}{l}\text { VPA: } 850 \mathrm{mg} \\
\text { CBZ: } 600 \mathrm{mg} \\
\text { LEV: } 1200 \mathrm{mg}\end{array}$ & $\begin{array}{l}\text { VPA: } 1100 \mathrm{mg} \\
\text { CBZ: } 500 \mathrm{mg} \\
\text { LEV: } 1600 \mathrm{mg}\end{array}$ & $\begin{array}{l}\text { VPA: } 700 \mathrm{mg} \\
\text { CBZ: } 600 \mathrm{mg} \\
\text { LEV: } 1200 \mathrm{mg}\end{array}$ \\
\hline Kórházban töltött idő (nap) & 6,1 nap (3-21 nap) & 6,6 nap (3-23 nap) & 7,2 nap (3-21 nap) \\
\hline Reoperáció (\%) & $27,8 \%(\mathrm{n}=10)$ & $33,3 \%(\mathrm{n}=8)$ & $40 \%(\mathrm{n}=8)$ \\
\hline Másodvonalbeli terápia & $13,9 \%(\mathrm{n}=5)$ & $20,8 \%(\mathrm{n}=5)$ & $25 \%(\mathrm{n}=5)$ \\
\hline Tumorlokalizáció (\%) & $\begin{array}{l}\text { Frontalis: } 42 \%(\mathrm{n}=15) \\
\text { Temporalis: } 33 \%(\mathrm{n}=12) \\
\text { Parietalis: } 25 \%(\mathrm{n}=9)\end{array}$ & $\begin{array}{l}\text { Frontalis: } 67 \%(\mathrm{n}=16) \\
\text { Temporalis: } 12 \%(\mathrm{n}=3) \\
\text { Parietalis: } 21 \%(\mathrm{n}=5)\end{array}$ & $\begin{array}{l}\text { Frontalis: } 45 \%(\mathrm{n}=9) \\
\text { Temporalis: } 45 \%(\mathrm{n}=9) \\
\text { Parietalis: } 10 \%(\mathrm{n}=2)\end{array}$ \\
\hline
\end{tabular}

$\mathrm{AED}=$ antiepileptikum; CBZ = karbamazepin; $\mathrm{LEV}=$ levetiracetám; TMZ = temozolomid; VPA = valproát 


\section{Statisztikai analizis}

Leíró statisztikát készítettünk a betegek adatainak ismertetéséhez. A csoportok progressziómentes túlélési (PFS-) és teljes túlélési (OS-) értékeit is vizsgáltuk, amihez Kaplan-Meier-formulát használtunk, majd log-rank teszteket végeztünk. A vizsgálat során $5 \%$-os szignifikanciahatárt szabtunk. A statisztikai próbák elkészítéséhez $\mathrm{R}$ szoftvert használtunk.

\section{Eredmények}

\section{Leiró statisztikai adatok és a szövettani kategóriák túlélési analizise}

A 2. táblázat tartalmazza a demográfiai és a klinikumra vonatkozó leíró statisztikai adatokat. A kiértékelés során 3 kategóriát képeztünk a hisztológiai karakterisztika alapján, így alakultak ki a glioblastoma ( $\mathrm{n}=36$ fó), a „nem glioblastoma, magas gradusú glioma” (non-GB HGG) ( $\mathrm{n}=24$ fó) és az LGG ( $\mathrm{n}=20$ fó) csoportok. Tumorrecidívának minősítettük azon eseteket, melyekben klinikai és/vagy radiológiai progresszió került leírásra. A fennmaradó hányad a stabil állapotú eseteket jelenti, nem a meggyógyult betegek százalékos arányát. A reoperációk és a másodvonali kezelések során tapasztalt alacsonyabb százalékos értékek a recidív esetekhez képest azért fordultak elő, mivel a betegség progressziója során kialakulhatott onkoterápiára alkalmatlannak minősített 'performance status' (teljesítményállapot) a

\section{PFS}

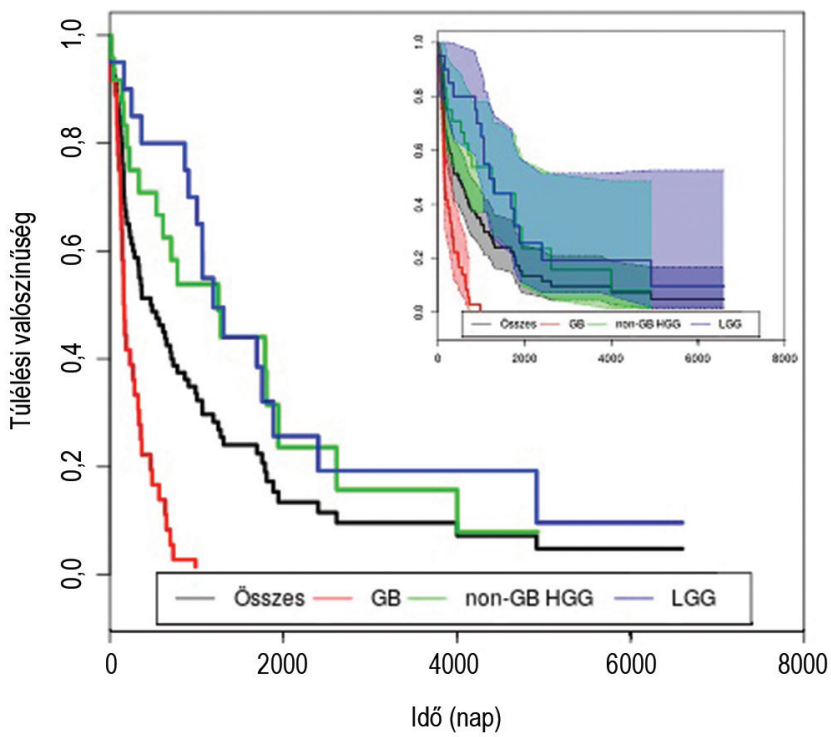

1. ábra $\begin{aligned} & \text { A szövettani kategóriák PFS-analízisének Kaplan-Meier-görbéi } \\ & \text { (a jobb felső sarokban a konfidenciaintervallummal kiegészített } \\ & \text { görbék láthatók) }\end{aligned}$
GB = glioblastoma; LGG = kis gradusú glioma; non-GB HGG
$=$ nem glioblastoma, nagy gradusú glioma (kivéve glioblasto-
ma); PFS = progressziómentes túlélés betegeknél, akiknél ezután már csak szupportív kezelés történt. Fontos megjegyezni, hogy a statisztikai elemzések az alacsony betegszám miatt fenntartásokkal kezelendők.

Az 1. ábra mutatja a szövettani kategóriák PFS-analízisének Kaplan-Meier-görbéit, és a kontrollidőpontokhoz tartozó PFS-valószínúségeket. Log-rank teszttel szignifikáns különbség mutatkozott a kategóriák között ( $\mathrm{p}=4.63 \mathrm{e}-09)$. A medián PFS-idő a glioblastomacsoport esetén 163 napnak (95\% CI: 135-325 nap), a nonGB HGG csoport esetén 1249 napnak (95\% CI: 6124002 nap), az LGG-csoport esetén 1193 napnak (95\% CI: 1003-NA nap) adódott.

A 2. ábrán láthatók a szövettani kategóriák által képzett csoportok OS-idejének analízise során nyert Kaplan-Meier-görbék, amelyek log-rank analízise során ismét szignifikáns különbség mutatkozott $(\mathrm{p}=4.02 \mathrm{e}-10)$. Csoportonként a következő medián túlélési időket találtuk: glioblastoma: 531 nap (95\% CI: 322-662 nap), non-GB HGG: 1782 nap (95\% CI: 1245-NA nap), LGG: 2145 nap (95\% CI: 1359-NA nap).

\section{Az antiepileptikumok hatása a túlélésve}

Az AED-k túlélésre gyakorolt hatásának vizsgálata során 4 csoportot alakítottunk ki: a valproát-, a LEV- és a CBZ-terápiában részesülő betegek csoportját és egy „Kontroll” csoportot, melybe antiepileptikus terápiában nem részesülő betegek kerültek. Az analízis során cél volt a lehetőség szerinti homogén kategóriák kialakítása

os

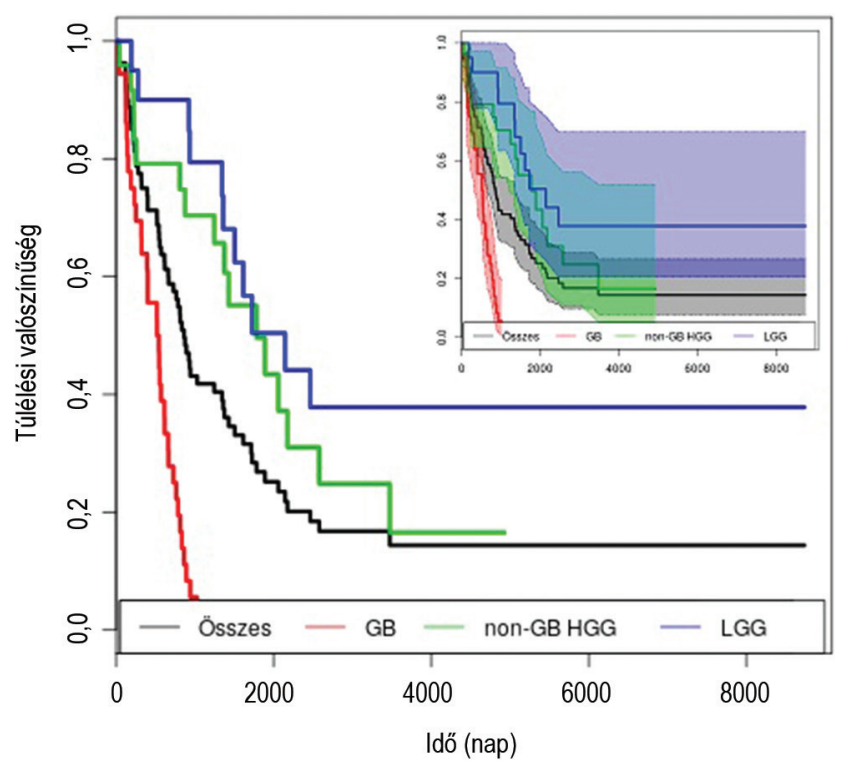

2. ábra $\mid$ A szövettani kategóriák OS-analízisének Kaplan-Meier-görbéi (a jobb felső sarokban a konfidenciaintervallummal kiegészített görbék láthatók)

$\mathrm{GB}=$ glioblastoma; LGG = kis gradusú glioma; non-GB HGG = nem glioblastoma, nagy gradusú glioma (kivéve glioblastoma); OS = teljes túlélés 
a retrospektív vizsgálat hátrányainak mérséklésére és az adatok hiteles interpretálására.

Kaplan-Meier-féle analízist végeztünk, mely grafikonja a 3. ábrán látható. A PFS tekintetében log-rank teszttel szignifikáns különbséget találtunk a kategóriák között $(\mathrm{p}=0,031)$, amely az AED-t szedő betegpopulációk

PFS

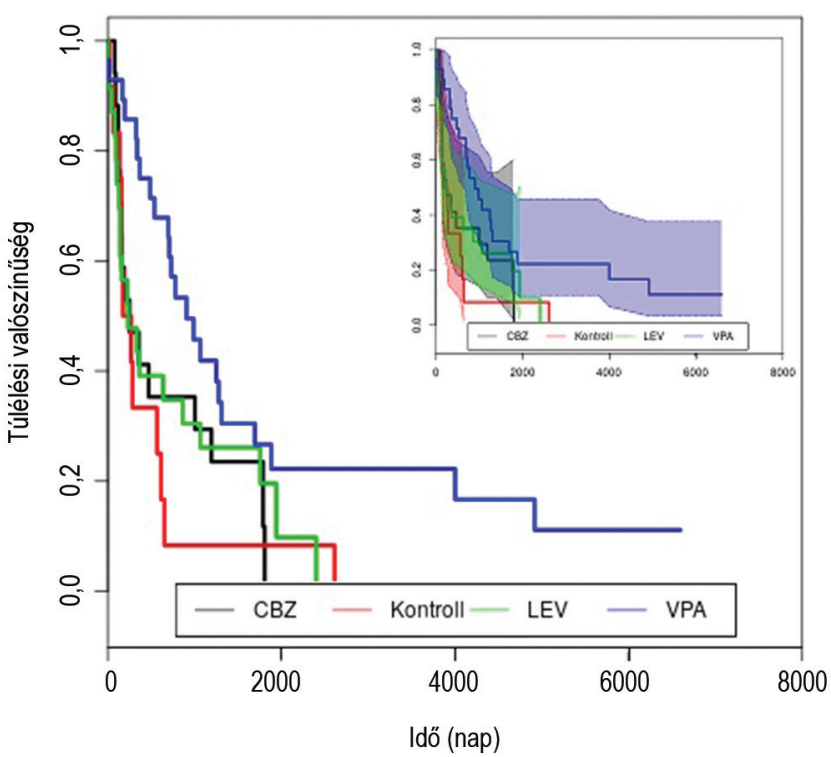

3. ábra $\quad$ A gyógyszeres terápia alapján képzett csoportok PFS-analízisének Kaplan-Meier-görbéi (a jobb felső sarokban a konfidenciaintervallummal kiegészített görbék láthatók)

$\mathrm{CBZ}=$ karbamazepin $; \mathrm{LEV}=$ levetiracetám; PFS = progresszió mentes túlélés; $\mathrm{VPA}$ = valproát

\section{PFS}

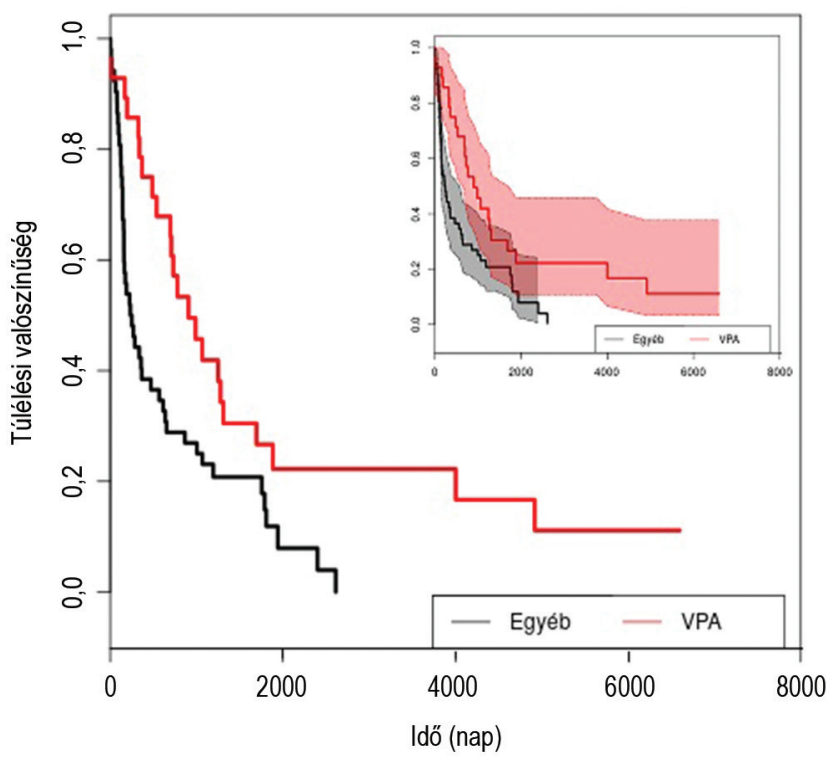

4. ábra

A VPA és a többi csoportból képzett populáció PFS-értékeiből képzett Kaplan-Meier-görbék (a jobb felső sarokban a konfidenciaintervallummal kiegészített görbék láthatók)

PFS $=$ progressziómentes túlélés $; \mathrm{VPA}=$ valproát idôbeli előnyét mutatja a gyógyszert nem szedő betegcsoporthoz képest: „Kontroll”: 220 nap (95\% CI: 157NA nap), CBZ: 249 nap (95\% CI: 154-NA nap), LEV: 232 nap (95\% CI: 142-1754 nap), valproát: 907 nap (95\% CI: 696-1883 nap). A valproát PFS-re gyakorolt hatását a valproátcsoport és a többi csoportból képzett

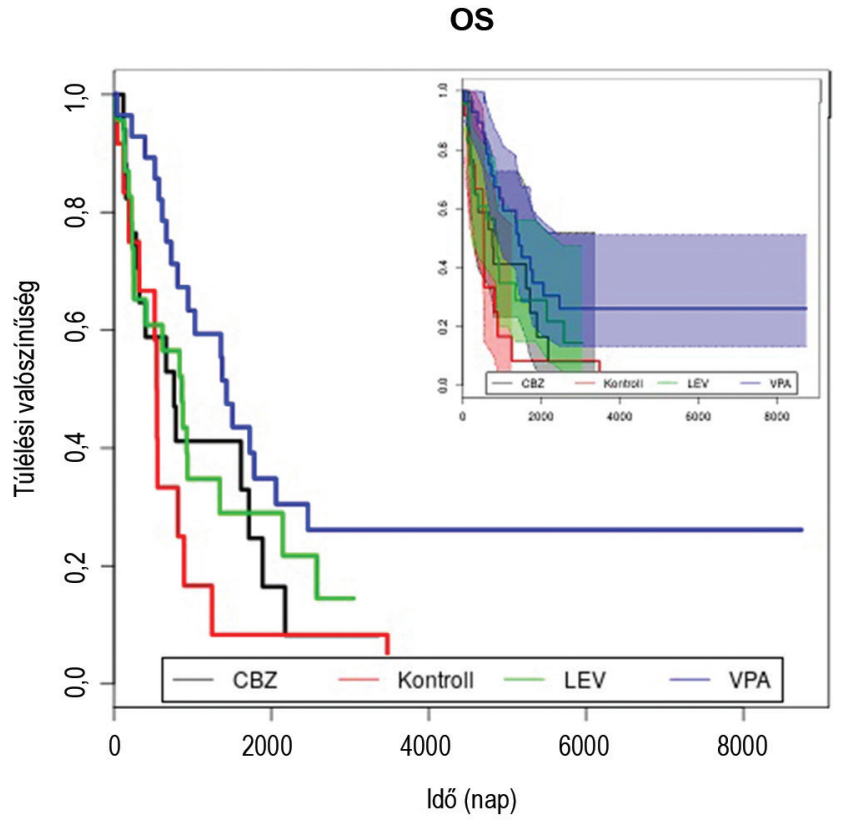

5. ábra $\quad$ A gyógyszeres terápia alapján képzett csoportok OS-analízisének Kaplan-Meier-görbéi (a jobb felső sarokban a konfidenciaintervallummal kiegészített görbék láthatók)

$\mathrm{CBZ}=$ karbamazepin; $\mathrm{LEV}=$ levetiracetám; OS = teljes túlélés; $\mathrm{VPA}=$ valproát

os

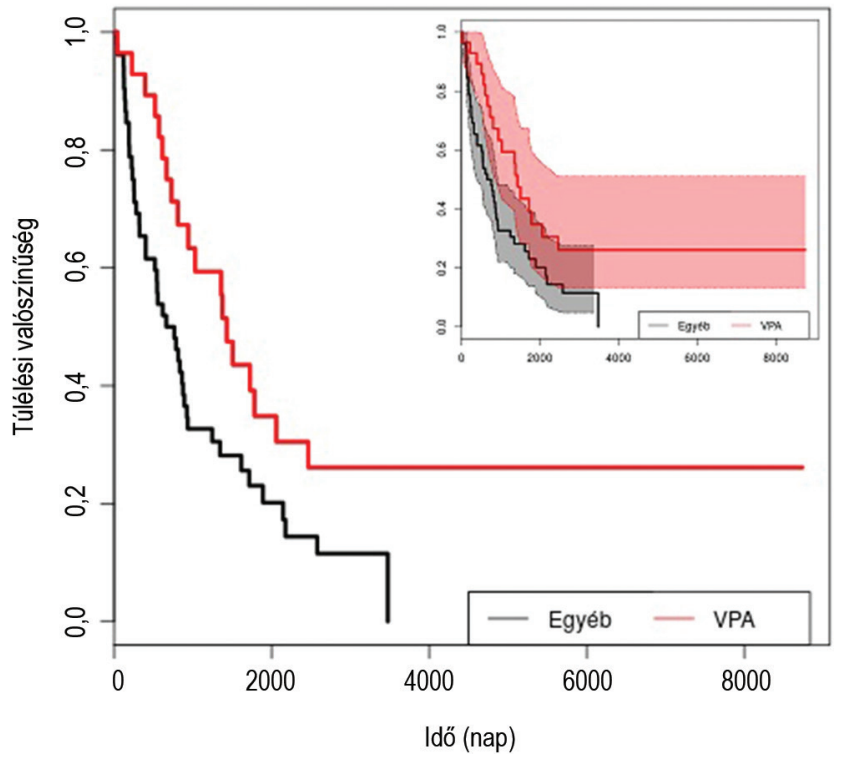

6. ábra képzett Kaplan-Meier-görbék (a jobb felső sarokban a konfidenciaintervallummal kiegészített görbék láthatók)

OS = teljes túlélés; $\mathrm{VPA}=$ valproát 
populáció összehasonlításával végeztük. A KaplanMeier-féle analízis eredményét a 4. ábra mutatja. Logrank teszttel szignifikáns különbséget találtunk a két kategória túlélési értékeit tekintve ( $\mathrm{p}=0,0058)$; a csoportok medián PFS-ideje a következő volt: valproát: 907 nap (95\% CI: 696-1883 nap), „Egyéb”: 240 nap (95\% CI: 157-612 nap).

Az OS-t vizsgálva kedvezőbb eredményeket kaptunk. A Kaplan-Meier-analízis eredményeit az 5. ábra mutatja. A valproátcsoportban a teljes medián túlélés 1429 napnak (95\% CI: 942-NA nap) adódott. LEV esetében 862 nap (95\% CI: 254-2578 nap), CBZ esetében 763 nap (95\% CI: 322-NA nap), az AED-vel nem kezelt betegpopulációban ez az érték 544 nap (95\% CI: 319-NA nap) volt. Log-rank teszttel összehasonlítottuk a Kaplan-Meier-görbéket, és a túlélési valószínüség szignifikáns különbségét találtuk a kategóriák között ( $\mathrm{p}=$ $0,0273)$. A valproát OS-re gyakorolt hatását a valproátcsoport és a többi csoportból képzett populáció („Egyéb”) összehasonlításával is elvégeztük. A KaplanMeier-analízis eredményei a 6 . ábrán láthatók. A valproáttal kezelt páciensek medián túlélése 1429 nap (95\% CI: 942-NA nap) volt, a többi csoport esetén ugyanez az érték 712 napnak (95\% CI: 401-934 nap) adódott. Logrank tesztet végeztünk a kategóriák túlélési idejének öszszehasonlítására: szignifikánsan magasabb OS-valószínúséget találtunk a valproátot szedő betegpopuláció esetén $(\mathrm{p}=0,015)$.

\section{Megbeszélés}

A glioblastoma, a non-GB HGG és az LGG onkológiai kezelése az utóbbi évek eredményei ellenére is megoldatlan problémát jelent. A maximális, biztonságos mútéti reszekció és az azt követő radioterápia jelentik a terápia bázisát, ami a pontos szövettani diagnózis ismeretében kemoterápiával (temozolomiddal - TMZ), másodvonalban biológiai terápiával (VEGF-inhibitor bevacizumabbal) egészíthető ki. A betegek medián túlélési adatai korrelálnak az irodalmi értékekkel, mely a glioblastomás betegcsoport esetén 17,7 hónapnak, non-GB HGG-s betegek esetén 59,4 hónapnak, az LGG-s betegpopuláció esetén 71,5 hónapnak adódott [17-19].

Az onkoterápia limitált lehetőségei miatt - az új terápiás lehetőségek kutatása mellett (például tirozin-kinázinhibitorok, tumorellenes vírusok, termoterápia stb.) - a jelenleg használt onkoterápia eredményességét kedvezően befolyásoló módszerek vizsgálata is folyamatosan zajlik. A radikális vagy szubtotális eltávolítást követő radioterápia időzítésével kapcsolatban találtak szignifikáns eredményeket a kutatók. Buszek és mtsai [20], Amsbaugh és mtsai [21] a mütétet követően 2 hónapnál később megkezdett radioterápia esetén számoltak be a túlélési idő csökkenéséről, így a radioterápia megfelelő időzítése is pozitívan befolyásolhatja a betegek túlélését. Ismert a malignus gliomák esetén a glükóz- és glutaminmetabolizmus jelentősége a daganat növekedésében (Warburg- effektus). Több állatkísérletben bebizonyosodott, hogy a ketogén diéta (magas zsír-, alacsony szénhidrát- és fehérjearányú makronutriens-bevitel) mellett kialakult metabolikus változások képesek fokozni a radiokemoterápia hatásosságát [22, 23]. Klinikai vizsgálatok bizonyították: a diéta biztonságosan használható, felnőtt és gyermek páciensek esetén is [24, 25], ám nagy esetszámú vizsgálatok szükségesek a gyakorlati hatásosság alátámasztására.

A valproát potenciális tumorellenes hatására a klinikusok lettek figyelmesek, amikor a szekunder epilepsziás rosszullétek miatt valproátterápiában részesülő betegek túlélési idejének növekedését észlelték az AED-ben nem részesülő populációhoz képest. In vitro vizsgálatokban bebizonyosodott a valproát erôs antitumorhatása; Lee és mtsai [26] glioblastoma-sejtkultúrán vizsgálták az AED-k növekedést gátló hatását. A kísérlet során a TMZ-n kívül a valproát és az oxikarbazepin esetén detektáltak 50\%-ot meghaladó növekedésinhibíciót. Krauze és mtsai [27] a fázis II. vizsgálatuk eredményei alapján ajánlják a valproátterápia további, fázis III. vizsgálatát. Watanabe és mtsai a valproátterápiában részesült pácienseik túlélési idejének növekedéséről és a radioterápia okozta hajhullás csökkenéséről számoltak be [28]. Az előző publikációhoz hasonlóan munkacsoportunk is a túlélési idő szignifikáns ( $\mathrm{p}=0,0273)$ növekedését észlelte a valproátterápiában részesülő betegeknél az OS tekintetében („valproát”: 47,6 hónap, „Kontroll”: 18,1 hónap). Esetünkben jelentős különbség, hogy szövettani szempontból nem homogén a populáció, LGG, non-GB HGG és glioblastoma egyaránt előfordul. A PFS tekintetében is szignifikáns különbséget $(\mathrm{p}=0,0058)$ tapasztaltunk, a túlélési értékek javuló tendenciáját észleltük a gyógyszert nem szedő kontrollcsoporthoz viszonyítva. Egyes publikációk megkérdőjelezik a valproát onkológiai hatékonyságát [29, 30], például Redjal és mtsai [31] csak glioblastoma esetén bizonyították az antitumorhatást, egyéb gliomák esetén egyenesen az OS-értékek csökkenését írták le.

Gyermekek esetében hasonló eredményekre jutottak a kutatók. Különbség, hogy gyermekeknél több szövettani típust is vizsgáltak a központi idegrendszeri daganatok közül. Felix és mtsai $[32,33]$ vizsgáltak supra-, infratentorialis és agytörzsi HGG-s, medulloblastomás, ependymomás betegeket egyaránt. Nem találtak szignifikáns mértékű növekedést a túlélési időben a profilaktikusan alkalmazott valproátterápia mellett, de a gyógyszerben részesült páciensek OS-értékében növekedés volt megfigyelhető. Wolff és mtsai bizonyították a 3 év feletti korosztály valproátterápiájának biztonságosságát [34], és a „HIT-GBM” protokoll valproáttal történő kiegészítése során a túlélési idő szignifikáns növekedését találták agytörzsi és egyéb lokalizációjú gyermekkori HGG-k kezelése kapcsán [35].

Kutatásunk során nehézséget okozott a valproátterápiában részesült/részesülő betegek esetszámának növelése. Ennek egyik oka a vizsgálat retrospektív jellege, 
azonban sebészi indok is létezik. Ismert az irodalomban a valproát thrombocytadiszfunkciót és thrombocytopeniát okozó mellékhatása [36, 37], mely intracranialis beavatkozások során nagy jelentőséggel bír a vérzéses szövődmények valószínűségének növelésével. Hauser és mtsai [38] lineáris összefüggést találtak a szedett valproát dózisa és a thrombocytaszám csökkenése között. Verrotti és mtsai [39] terápiás (átlag $60 \mu \mathrm{g} / \mathrm{ml}$ ) valproátszérumszint mellett észlelték a thrombocytopenia kialakulását betegeiknél. Nasreddine és mtsai [40] ennél magasabb szérumkoncentrációk mellett írták le a vérlemezkeszám csökkenését (nők: $100 \mu \mathrm{g} / \mathrm{ml}$, férfiak: 130 $\mu \mathrm{g} / \mathrm{ml}$ ). A vérzéses szövődmények kockázatát tovább növeli, hogy a számbeli csökkenés mellett aggregációs múködésbeli problémát is okozhat a gyógyszer. Antiaggregáns hatásának egyik oka az intracelluláris adenozintrifoszfát szintjének csökkenése. Hahn és mtsai [41] kutatásuk során a valproát és a lítium hatását vizsgálták a proteinkináz C (PKC) aktivációjára és ezen keresztül a G-protein-kapcsolt jelátviteli útvonalakra. Eredményeik értelmében a lítium és a valproát is az adagolás második hetét követően csökkentette a PKC transzlokációját - és így aktivitását - a citoszolikus és a membránhoz kötött formákban.

Habár a valproát vérlemezke-diszfunkciót okozó hatását direkten - az aszpirinhez vagy a klopidogrélhez hasonlóan - monitorozni nem tudjuk, a fenti eredményekre tekintettel javasoljuk terápiás dózisban valproátterápiában részesülő betegek intracranialis mütéténél a thrombocytatranszfúzió profilaktikus alkalmazását!

\section{Következtetés}

Számos tudományos közlemény foglalkozik az AED-k tumorellenes hatásával, és e tekintetben a valproát kapta a legnagyobb figyelmet az in vitro és in vivo kísérletek során nyert eredmények alapján. A klinikai vizsgálatok és a publikációk többsége a biztonságos használatát és a túlélésre gyakorolt pozitív hatását bizonyítják.

Vizsgálatunk során magyar, supratentorialis gliomában szenvedő betegpopulációt vizsgáltunk egy országos intézmény adatai alapján. Az AED-t szedő betegek PFSés OS-értékeiben pozitív változásokat észleltünk az AED-t nem szedő kontrollcsoporthoz képest. Alacsony esetszámú vizsgálatunk alapján úgy tünik, hogy a valproátot szedő betegek hosszabb túlélést mutatnak ugyanazon standard idegsebészi és onkológiai kezelés mellett. Az irodalmi adatok és kutatásunk alapján megfontolandónak tartjuk a valproát első vonalban történő alkalmazását onkoterápiában is részesülö, epilepsziás, gliomában szenvedő betegek esetén, amennyiben annak hatásosságát jól kontrollált, nagyobb esetszámú prospektív kohorszvizsgálat is alátámasztja.
Anyagi támogatás: A kézirat az Innovációs és Technológiai Minisztérium ÚNKP-20-3-I kódszámú Új Nemzeti Kiválósági Programjának a Nemzeti Kutatási, Fejlesztési és Innovációs Alapból finanszírozott szakmai támogatásával készült. A kutatást részben az Innovációs és Technológiai Minisztérium Tématerületi Kiválósági Programja (2020-4.1.1.-TKP2020) támogatta a Semmelweis Egyetem Digitális Biomarker tématerületi programja keretében, és az NKFIH K128780. számú pályázat.

Szerzôi munkamegosztás: M. T.: A kutatási terv felállítása, a kutatás megszervezése, az adatok kiértékelése, a kézirat megírása és szerkesztése. M. D.: A retrospektív betegpopuláció adatbázisának felépítése, irodalomkutatás. P. P.: Statisztikai kiértékelés, a kézirat megírása. B. A. Gy.: Idegsebész-onkológusként a betegek kezelőorvosa, irodalomkutatás, a kézirat szerkesztése. F. I.: Idegsebészonkológusként a betegek kezelőorvosa, a kézirat szerkesztése. B. P.: A kutatás tervezése, adatelemzés, a cikk megírása és szerkesztése. S. L.: A kutatás vezetője, idegsebész-onkológusként a betegek kezelőorvosa, a kézirat megírása és szerkesztése. A cikk végleges változatát valamennyi szerző elolvasta és jóváhagyta.

Érdekeltségek: A szerzőknek nincsenek érdekeltségeik.

\section{Köszönetnyilvánítás}

Köszönjük Kenessey István fooorvos úrnak és a Nemzeti Rákregiszter munkatársainak a közremúködést, a halálozási adatok rendelkezésünkre bocsátását

\section{Irodalom}

[1] Lukas RV, Wainwright DA, Ladomersky E, et al. Newly diagnosed glioblastoma: a review on clinical management. Oncology (Williston Park, United States) 2019; 33: 91-100.

[2] Omuro A, DeAngelis LM. Glioblastoma and other malignant gliomas: a clinical review. JAMA 2013; 310: 1842-1850.

[3] Stupp R, Mason WP, van den Bent MJ, et al. Radiotherapy plus concomitant and adjuvant temozolomide for glioblastoma. $\mathrm{N}$ Engl J Med. 2005; 352: 987-996.

[4] Stupp R, Hegi ME, Mason WP, et al. Effects of radiotherapy with concomitant and adjuvant temozolomide versus radiotherapy alone on survival in glioblastoma in a randomised phase III study: 5-year analysis of the EORTC-NCIC trial. Lancet Oncol. 2009; 10: 459-466.

[5] Czigléczki G, Sinkó D, Benkő Zs, et al. The effect of bevacizumab monotherapy on progression-free survival in recurrent glioblastoma. [A bevacizumab-monoterápia hatása a progressziómentes túlélésre rekurrens glioblastomában szenvedő betegek esetében.] Ideggyógy Szle. 2019; 72: 153-158. [Hungarian]

[6] Englot DJ, Chang EF, Vecht CJ. Epilepsy and brain tumors. Handb Clin Neurol. 2016; 134: 267-285.

[7] Kim OJ, Yong Ahn J, Chung YS, et al. Significance of chronic epilepsy in glial tumors and correlation with surgical strategies. J Clin Neurosci. 2004; 11: 702-705.

[8] Lee JW, Wen PY, Hurwitz S, et al. Morphological characteristics of brain tumors causing seizures. Arch Neurol. 2010; 67: 336342 . 
[9] Blümcke I, Luyken C, Urbach H, et al. An isomorphic subtype of long-term epilepsy-associated astrocytomas associated with benign prognosis. Acta Neuropathol. 2004; 107: 381-388.

[10] Lote K, Stenwig AE, Skullerud K, et al. Prevalence and prognostic significance of epilepsy in patients with gliomas. Eur J Cancer 1998; 34: 98-102.

[11] Stupp R, Janzer RC, Hegi ME, et al. Prognostic factors for lowgrade gliomas. Semin Oncol. 2003; 30(6 Suppl 19): 23-28.

[12] Chen DY, Chen CC, Crawford JR, et al. Tumor-related epilepsy: epidemiology, pathogenesis and management. J Neurooncol. 2018; 139: 13-21.

[13] Göttlicher M, Minucci S, Zhu P, et al. Valproic acid defines a novel class of HDAC inhibitors inducing differentiation of transformed cells. EMBO J. 2001; 20: 6969-6978.

[14] Hrebackova J, Hrabeta J, Eckschlager T. Valproic acid in the complex therapy of malignant tumors. Curr Drug Targets 2010; 11: 361-379.

[15] Hosein AN, Lim YC, Day B, et al. The effect of valproic acid in combination with irradiation and temozolomide on primary human glioblastoma cells. J Neurooncol. 2015; 122: 263-271.

[16] Brown SL, Kolozsvary A, Liu J, et al. Histone deacetylase inhibitors protect against and mitigate the lethality of total-body irradiation in mice. Radiat Res. 2008; 169: 474-478.

[17] Ostrom QT, Bauchet L, Davis FG, et al. The epidemiology of glioma in adults: a "state of the science review". Neurooncol. 2014; 16: 896-913

[18] Nayak L, Reardon DA. High-grade gliomas. Continuum lifelong learning. Neurooncology 2017; 23: 1548-1563.

[19] Schiff D. Low-grade gliomas. Continuum lifelong learning. Neurooncology 2017; 23: 1564-1579.

[20] Buszek SM, Al Feghali KA, Elhalawani H, et al. Optimal timing of radiotherapy following gross total or subtotal resection of glioblastoma: a real-world assessment using the National Cancer Database. Sci Rep. 2020; 10: 4926

[21] Amsbaugh MJ, Yusuf M, Gaskins J, et al. The impact of timing of adjuvant therapy on survival for patients with glioblastoma: an analysis of the National Cancer Database. J Clin Neurosci. 2019; 66: 92-99.

[22] Woolf EC, Scheck AC. The ketogenic diet for the treatment of malignant glioma. J Lipid Res. 2015; 56: 5-10.

[23] Mukherjee P, Augur ZM, Li M, et al. Therapeutic benefit of combining calorie-restricted ketogenic diet and glutamine targeting in late-stage experimental glioblastoma. Commun Biol. 2019; 2: 200

[24] van der Louw EJ, Olieman JF, Catsman-Berrevoets CE, et al. Ketogenic diet treatment as adjuvant to standard treatment of glioblastoma multiforme: a feasibility and safety study. Ther Adv Med Oncol. 2019; 11: 1758835919853958. Doi: 10.1177/ 1758835919853958.

[25] van der Louw EJ, Reddingius RE, Olieman JF, et al. Ketogenic diet treatment in recurrent diffuse intrinsic pontine glioma in children: a safety and feasibility study. Pediatr Blood Cancer 2019; 66: e27561.

[26] Lee CY, Lai HY, Chiu A, et al. The effects of antiepileptic drugs on the growth of glioblastoma cell lines. J Neurooncol. 2016; 127: $445-453$.

[27] Krauze AV, Myrehaug SD, Chang MG, et al. A phase 2 study of concurrent radiation therapy, temozolomide, and the histone deacetylase inhibitor valproic acid for patients with glioblastoma. Int J Radiat Oncol Biol Phys. 2015; 92: 986-992.

[28] Watanabe S, Kuwabara Y, Suehiro S, et al. Valproic acid reduces hair loss and improves survival in patients receiving temozolomide-based radiation therapy for high-grade glioma. Eur J Clin Pharmacol. 2017; 73: 357-363.

[29] Happold C, Gorlia T, Chinot O, et al. Does valproic acid or levetiracetam improve survival in glioblastoma? A pooled analysis of prospective clinical trials in newly diagnosed glioblastoma. J Clin Oncol. 2016; 34: 731-739.

[30] Tsai HC, Wei KC, Tsai CN, et al. Effect of valproic acid on the outcome of glioblastoma multiforme. Br J Neurosurg. 2012; 26: 347-354.

[31] Redjal N, Reinshagen C, Le A, et al. Valproic acid, compared to other antiepileptic drugs, is associated with improved overall and progression-free survival in glioblastoma but worse outcome in grade II/III gliomas treated with temozolomide. J Neurooncol. 2016; 127: 505-514.

[32] Felix FH, Trompieri NM, de Araujo OL, et al. Potential role for valproate in the treatment of high-risk brain tumors of childhood-results from a retrospective observational cohort study. Pediatr Hematol Oncol. 2011; 28: 556-570.

[33] Felix FH, de Araujo OL, Da Trindade KM, et al. Survival of children with malignant brain tumors receiving valproate: a retrospective study. Child's Nerv Syst. 2013; 29: 195-197.

[34] Wolff JE, Driever PH, Erdlenbruch B, et al. Intensive chemotherapy improves survival in pediatric high-grade glioma after gross total resection: results of the HIT-GBM-C protocol. Cancer 2010; 116: 705-712.

[35] Wolff JE, Kramm C, Kortmann RD, et al. Valproic acid was well tolerated in heavily pretreated pediatric patients with high-grade glioma. J Neurooncol. 2008; 90: 309-314.

[36] Anderson GD, Temkin NR, Chandler WL, et al. Effect of valproate on hemostatic function in patients with traumatic brain injury. Epilepsy Res. 2003; 57: 111-119.

[37] Koenig S, Gerstner T, Keller A, et al. High incidence of vaproateinduced coagulation disorders in children receiving valproic acid: a prospective study. Blood Coagul Fibrinolysis 2008; 19: 375382.

[38] Hauser E, Seidl R, Freilinger M, et al. Hematologic manifestations and impaired liver synthetic function during valproate monotherapy. Brain Dev. 1996; 18: 105-109.

[39] Verrotti A, Greco R, Matera V, et al. Platelet count and function in children receiving sodium valproate. Pediatr Neurol. 1999; 21: 611-614

[40] Nasreddine W, Beydoun A. Valproate-induced thrombocytopenia: a prospective monotherapy study. Epilepsia 2008; 49: 438445.

[41] Hahn CG, Umapathy, Wang HY, et al. Lithium and valproic acid treatments reduce PKC activation and receptor-G protein coupling in platelets of bipolar manic patients. J Psychiatr Res. 2005; 39: 355-363.

(Mezei Tamás dr., Budapest, Amerikai út 57., 1145 e-mail: mezei.tamas@semmelweis-univ.hu)

A cikk a Creative Commons Attribution 4.0 International License (https://creativecommons.org/licenses/by/4.0/) feltételei szerint publikált Open Access közlemény melynek szellemében a cikk bármilyen médiumban szabadon felhasználható, megosztható és újraközölhetö, feltéve, hogy az eredeti szerző és a közlés helye, illetve a CC License linkje és az esetlegesen végrehajtott módositások feltüntetésre kerülnek. (SID_1) 